\title{
Quantitative Analysis of Sustainable Transport Development as a Support Tool for Transport System Management: Spatial Approach
}

\author{
Artur Czech ${ }^{1}$, Katarzyna Gralak ${ }^{2}$ D, Marzena Kacprzak ${ }^{2, *(D)}$ and Agnieszka Król ${ }^{1}$ (D) \\ 1 Institute of Management and Technical Sciences, Warsaw Management University, 03-772 Warsaw, Poland; \\ artur.czech@wsm.warszawa.pl (A.C.); agnieszka.krol@wsm.warszawa.pl (A.K.) \\ 2 Department of Development Policy and Marketing, Institute of Economics and Finance, Warsaw University \\ of Life Sciences-SGGW, 02-787 Warsaw, Poland; katarzyna_gralak@sggw.edu.pl \\ * Correspondence: marzena_kacprzak@sggw.edu.pl
}

Citation: Czech, A.; Gralak, K.; Kacprzak, M.; Król, A. Quantitative Analysis of Sustainable Transport Development as a Support Tool for Transport System Management: Spatial Approach. Energies 2021, 14, 6149. https://doi.org/10.3390/ en14196149

Academic Editor: Dalia Štreimikienè

Received: 3 August 2021

Accepted: 23 September 2021

Published: 27 September 2021

Publisher's Note: MDPI stays neutral with regard to jurisdictional claims in published maps and institutional affiliations.

Copyright: (c) 2021 by the authors. Licensee MDPI, Basel, Switzerland. This article is an open access article distributed under the terms and conditions of the Creative Commons Attribution (CC BY) license (https:// creativecommons.org/licenses/by/ $4.0 /)$.

\begin{abstract}
The main aim of this paper is to assess sustainable transport development, particularly in Polish voivodeships, as well as to identify underdeveloped geographical areas. In order to deal with this research topic, both classical and multivariate order statistical measures were implemented into the research process. The source of information for the research was the data drawn from BDL (Bank of Local Data) Statistics Poland. The rankings of Polish voivodeships were obtained for sustainable transport development and its individual components in the form of three orders: environmental, social and economic. This allowed us to identify underdeveloped regions in the area of transport sustainability and its particular aspects. It should be noted that we applied both the original set of diagnostic variables and their classification into particular orders. However, the choice of variables was mostly conditioned by the availability of data. Furthermore, this was the first time that the taxonomic methods applied here, featuring the implementation of the multidimensional Weber median, have been used to assess aspects of transport sustainability. This kind of synthetic method design allowed us to consider the interactions between different areas of a sophisticated transportation system and made our analysis immune to skewing by diagnostic variables.
\end{abstract}

Keywords: sustainable development; means of transport; infrastructure management; greenhouse gas emission; climate change; pollution; taxonomic analysis; synthetic measure; spatial assessment

\section{Introduction}

Poland's accession to the European Union led to its adoption of the strategic aims of the European Union's transport policy. This was due to the fact that transportation is considered one of the main components of sustainable development. Moreover, mobility has a significant influence on the European Union and its environment [1]. Nevertheless, each transport activity generates external effects, both positive and negative. The positive effects include the achievement of economic goals, such as the production of goods and delivering them to the market. Therefore, transport stimulates economic growth, creates workplaces and influences quality of life. The negative effects include such problems as greenhouse gas emissions, global warming, accidents, etc., which affect both humans' wellbeing and quality of life. According to one European Union report, air pollution causes up to four hundred thousand premature deaths each year [2]. Furthermore, transport has already been identified as the fastest-growing source of greenhouse gas emissions. Nevertheless, transport is still considered to be the basic factor of development in many countries, on both a macro- and microeconomic scale. Furthermore, transport is considered one of the cornerstones of globalization [3]. All of these factors create a lot of pressure to implement policies in order to reduce pollution, noise emission, oil consumption and the number of accident victims. One of the main areas of focus in the European Union's 
plans for climate protection is decarbonization. This kind of activity is covered in European Union documents in the form of the elimination the carbon dioxide [4]. Moreover, one of the purposes of the European Union is to create a competitive and resource-efficient transport system in order to significantly reduce greenhouse gas emissions [5].

It should be noted that Poland is a diverse region, both in terms of its socio-economic development and its natural environment pollution. Consequently, all activities should be balanced in order not to destabilize the economy and instead to help society and protect the natural environment. Therefore, a sustainable mobility system, allowing citizens and goods to move freely and safely while respecting the environment, is crucial for quality of life and the health of the economy [6].

However, transport in Poland as a part of the European Union should be considered as a sustainable system of interrelated components. On the one hand, relationships in the area of transport sustainability are mutual and very hard to quantify, because transport can be considered as a complex phenomenon in which indirectly observable interactions play a key role. On the other hand, Poland is diverse, which is reflected in the level of socio-economic development of its different voivodeships. These spatial units have large disparities among themselves. However, transport is considered as a main factor in the process of reducing regional and social disparities in the European Union [7].

Therefore, it is necessary to make a reliable diagnosis of the sustainable transport development level in particular provinces of Poland, i.e., voivodeships. Moreover, this kind of analysis can be considered as the basis for the implementation of the support policy delivered from European Union institutions.

The main aim of the paper is to assess sustainable transport development in particular voivodeships (provinces). Apart from that, our research also allowed us to identify the underdeveloped geographical areas in Poland as the basis of the implementation of the support policy in the area of transportation.

The article is devoted to the analysis of the broadly understood issue of transport development in light of the implementation of economic and sustainable development policy. Its detailed purpose is to assess the level of sustainability of transport development, which is considered an important element contributing to the achievement of an integrated order in the world economy. The first part of the article discusses selected aspects of sustainable transport development. Next, based on research experience, the measures for sustainable transport development at the regional level are reviewed. Examples of measures and indicators of sustainable transport, developed for the needs of transport management at the regional level, are presented. In addition, the article assesses the possibility of using the identified measures in business practice, and indicates directions for further research.

The research methodology adopted a set of hard (objective) indicators, which were constructed on the basis of available statistical data. The research data were drawn from BDL (Bank of Local Data) Statistics Poland. The elaboration was based on a literature review and a multidimensional analysis implementing the chosen taxonomic methods, both classical and order. The latter allowed to consider interactions within the set of diagnostic variables, which was very important for the research carried out for this study.

\section{Literature Review}

The literature review showed that the concept of sustainable development is widely known and has already been used for many years in scientific literature, strategic documents and legal acts. Moreover, it is still the subject of scientific debate, as well as constant investigation in the pursuit of more effective methods and means of action at all levels of development management.

The concept of sustainable development, publicized in 1987 by the United Nations' World Commission on Environment and Development [8], grew out of the need to counteract environmental degradation, and quickly embraced the social and economic aspects of development [9]. Since then, it has been enriched by the contribution of various scientific 
disciplines, so that it has become the basic paradigm of all development programs, policies and strategies formulated by international organizations, national governments and local government bodies. Its essence is still to ensure a lasting improvement in the quality of life of modern and future generations by shaping rational proportions between various types of capital: economic, human, social and natural [10].

The concept of sustainable development assumes the achievement of goals in three key areas: social, economic and environmental [11-15]. This requires a holistic approach because of the interrelationships and interdependencies between these areas. Due to the multitude of these relations and the difficulty in quantifying them, knowledge about the effects of sustainable development is not complete.

The concept of sustainable development applies to all areas of social life and all sectors of the economy. Therefore, transport is one of the many strategic areas of the sustainable development policy. On the one hand, it determines the competitiveness of a country's economy and individual regions [16,17]. On the other hand, it is the source of many significant externalities, which have negative effects on society and the environment (the so-called external costs) [18-20]. The impact of transport on the basic elements of sustainable development, i.e., environmental, social and economic, has already been identified in previous research [21]. The environmental aspects include factors such as: air and water pollution, habitat loss, hydrologic impact and the depletion of non-renewable resources. The social aspects include the following phenomena: inequity of impact, mobility disadvantages, the impact on human health and community interaction and its livability, as well as aesthetics. The economic factors encompass traffic congestion, mobility barriers, damage from accidents, facility and consumer costs and the depletion of non-renewable resources.

Therefore, the scale of the external costs of transport is considered a serious problem for most European Union member states, especially Poland. This is due to the fact that the major role, in both freight and passenger transport in Poland, played by road transport. For example, the share of roads in cargo transport in 2019 was 86.5\%; in passenger transport, it was $50.8 \%$. Moreover, the market needs resulting from the increase of goods exchange and the mobility of citizens mean that the demand for transport is aimed mainly at road transport. It should be mentioned that the increase in the use of passenger cars in Poland has occurred since the beginning of the 1990s and is a consequence of free access to these means of transport and the increase in the wealth of Polish society [22]. This has led to a higher level negative external effects, such as environmental pollution (mainly through the emission of harmful gases and dust), the emission of noise and vibrations, accidents, transport congestion, the destruction of infrastructure, land occupancy and climate change. Our literature review showed that the external costs of transport in Poland are thought to be $5 \%$ of Gross Domestic Product [23].

These problems form the impetus behind the desire to create a coherent and efficiently functioning transport system in Poland, integrated within the European and global system [24]. A modern transport system, which is an integral component of the European logistics system, should be created and shaped in accordance with the requirements of the sustainable development strategy [25].

It should be noted that, on theoretical grounds, no uniform, universally accepted definition of sustainable transport has been developed so far. Based on the literature review, narrow and broad approaches to the definition of this concept can be distinguished $[21,26]$.

On the one hand, the narrow approach emphasizes the environmental aspects of transport balancing. The most important conditions enabling the implementation of an environmentally sustainable transport system are: the protection of human health, ensuring the integrity of ecosystems; respecting health and environmental constraints (levels and critical loads); preventing and minimizing emissions from polluting substances; guaranteeing the sustainable use of non-renewable and renewable resources; and avoiding man-made changes to global environmental systems [27]. In narrow terms, environmentally sustainable transport enables the achievement of generally accepted environmental health and quality objectives; it is compatible with the integrity of the ecosystem and does not 
exacerbate adverse global phenomena, such as climate change and stratospheric ozone depletion.

On the other hand, in the broad approach, sustainable transport is treated in the convention of an integrated order, i.e., in the context of a broad definition of sustainable development [28]. Within the broad approach, a sustainable transport system means that cargo and passenger transport are carried out in a way that simultaneously takes into account and reconciles environmental, social and economic criteria. Accordingly, sustainable transport should provide safe, economically viable and socially acceptable accessibility to human and work centers; it should be affordable and offer a choice of modes $[5,29,30]$.

Attention should be paid to the process approach to sustainable transport, which is defined as sustainable transport development. In scientific research, this concept is understood as a planning concept that constitutes a long-term, integrated action plan. It assumes a patchwork approach to achieving strategic goals in the field of the transport system, which are embedded in the overall strategy of sustainable development. The first dimension of these objectives, the economic, is expressed in the desire to improve the economic efficiency of passenger and cargo transport. In the social dimension, activities are directed towards increasing the accessibility, quality and safety of transport. The third dimension, the environmental, is aimed, inter alia, at the reduction of environmental pollution and greenhouse gas emissions, energy consumption and noise emissions.

In Polish research, sustainable development is also commonly considered under the three categories: social, economic and environmental [31-33]. The increased understanding resulting from this research has led to further categorization: a distinction has been made between the institutional and political order and the social order [34]; and a distinct geographical order has been categorized within the environmental order [35,36]. It should be noted that an attempt to achieve harmony between partial orders is referred to as an integrated order. An integrated order can be defined as a positive target state of developmental changes combining partial orders in a coherent, consistent way [31]. At the same time, sustainable development cannot be equated with an integrated order, because the first concept is a process, while the second is a target.

The balancing process in relation to the transport system should be permanent and should be carried out with the same intensity in each of the dimensions of the transport system. This process leads to the construction of an integrated order within the transport system and in its relations with the environment. An integrated order means that in the process of its development, the transport system has already reached the desired level in terms of individual partial orders (social, economic and environmental) and all of them are so coherent that they give it a qualitatively new dimension-full systemic integration, rather than partial [37]. Such a transport system, which ensures an integrated order, can only be considered modern. It meets the social, economic and environmental expectations of the current generation, while orienting the transport sector to the needs of future generations.

Our literature study proved that transport sustainability is a process of constant changes and that it must be carefully managed and monitored to be fully achieved. Therefore, the implementation of a sustainable transport development policy requires the selection of appropriate measures that can be used in the assessment process. It should be mentioned that the requirement of sustainability in the transportation area increases the complexity of its measurement. Additionally, the multidimensionality of transport creates a number of difficulties in the assessment of spatial objects, which are submitted to statistical investigation with a number of diagnostic variables.

It should be noted that there are two approaches that can be implemented in spatial objects assessment in the area of transportation [38]. The first is one-dimensional analysis, where levels of transport development are evaluated separately according to particular variables. The second implements taxonomic tools, which create opportunities to support 
logistics policy by ordering and classifying research objects, which are described by many variables.

The literature review showed that transport sustainability has already been investigated several times [39-43]. In addition to the approaches already mentioned, a particularly interesting approach was the creation of smart indicators in the following areas: social transportation, environmental transportation, economics transportation and innovation transportation [44].

However, studies in the area of transport sustainability with different methodological implementation in the research process, including taxonomic measures, among others, have already appeared. In one, a combination of different research methods, such as, PCA, Fuzzy Logic and equal weighting, was implemented in order to construct the composite index [45]. Going further, a three-steps procedure was applied as well [46]. In addition to the presented literature approaches, it should be noted that the equal weighting of diagnostic variables is often used in scientific studies of transportation [47,48].

Nevertheless, much less attention has been devoted to the investigation of mutual, but not directly observable, relationships, otherwise known as "interactions". It should be mentioned that including such relationships in the research on transport sustainability is very important form the point of view of geographical analysis. However, the empirical assessment of geographical transport development with the implementation of taxonomic methods has already been carried out [49-54], although it did not include interactions in the area of transport sustainability. The question of how to take interactions into account in transport research has already been indicated in previous literature reviews [55-57].

Summing up the above considerations, sustainable development is widely referenced in scientific literature, strategic documents and legal acts. Nevertheless, it is still the subject of scientific debate and research is still underway in order to find more effective methods that can be implemented in its geographical assessment. However, the existing regional analyses in the area of transport sustainability do not include interactions in its set of diagnostic variables.

\section{Presentation of Research Methods and Selection of Potential Data Set}

The implemented research methods, both classical and order, are based on synthetic measure construction in two basic ways.

The former, classical approach, uses statistical measures, such as arithmetic mean and standard deviation. In this case, the particular values of synthetic measurement were calculated according to the following formula [58]:

$$
M K_{i}=1-\frac{d_{i}}{\bar{D}+2 \times S_{D}}
$$

where:

$d_{i}$-individual values of the distance vector $D$,

$D=\left(d_{1}, d_{2}, \ldots, d_{n}\right)$-distance vector,

$i=1,2, \ldots, n-i$-th province (voivodeship),

$n$-the number of provinces (voivodeships), $\stackrel{D}{D}$-mean of distance vector $D$ and $S_{D}-$ standard deviation of distance vector $D$. The individual elements of the distance vector $D$ were obtained using an urban metric, also known as a taxi, according to the following formula:

$$
d_{i}=\sum_{j=1}^{m}\left|z_{i j}-\phi_{j}\right|
$$

where $\phi_{j}$ are considered as the elements of the development pattern. Their individual values were determined in accordance with the approach presented by Młodak [59] i.e., the maximum values of the standardized variables were assumed for the stimulants, the minimum values for the destimulants, and the nominal values for the nominants.

The latter, order approach, introduces the multidimensional median vector as well as mad (median absolute deviation). This method was implemented into the research process 
by Polish statisticians [60]. The diagnostic variables that describe the phenomenon under statistical investigation are standardized with the following equation [59]:

$$
z_{i j}=\frac{x_{i j}-\theta_{j}}{1.4826 \times \operatorname{mad}\left(X_{j}\right)}
$$

where:

$x_{i j}$-value of the $j$-th variable for $i$-th province (voivodeship),

$i=1,2, \ldots, n-i$-th province (voivodeship),

$n$-the number of voivodeships,

$j=1,2, \ldots, m-j$-th diagnostic variable,

$M$-the number of diagnostic variables,

$\theta_{j}$ - particular values of the multidimensional median vector $\Theta$ (border or Weber),

1.4826 - constant coefficient estimated in empirical studies,

$\operatorname{mad}\left(X_{j}\right)$-median absolute deviation of the $j$-th variable.

The particular values of $\theta_{j}$ are considered as the elements of the multidimensional median vector i.e., border or Weber. On the one hand, the estimation of the border median vector relies on calculating the median separately for each of the variables. In this case, these medians are adopted as individual elements of the above-mentioned multivariate median.

On the other hand, the Weber median is calculated in the minimalization process of the following formula:

$$
T\left(\Theta, R^{m}\right)=\operatorname{argmin}_{\Theta \in R^{m}}\left\{\sum_{i=1}^{n}\left[\sum_{j=1}^{m}\left(x_{i j}-\theta_{j}\right)^{2}\right]^{1 / 2}\right\}
$$

where:

$m$ - the number of diagnostic variables,

$R^{m}-m$-dimensional space of real numbers,

$\theta_{j}$ - particular values of multidimensional Weber median $\Theta$,

$j=1,2, \ldots, m-j$-th diagnostic variable,

$\Theta=\left(\theta_{1}, \theta_{2}, \ldots, \theta_{m}\right)$-multidimensional Weber median,

$x_{i j}$-value of the $j$-th variable for $i$-th province (voivodeship),

$i=1,2, \ldots, n-i$-th province (voivodeship),

$n$-the number of voivodeships.

Therefore, a point in a multidimensional space should be determined, where the sum of the Euclidean distances of this point from other objects in this space tends to a minimum. It should be noted that this kind of multidimensional median vector both makes the analysis immune to skewing and takes into account interactions. Furthermore, when constructing synthetic measure, it is very important to include such relations from the point of view of the taxonomic analysis of complex phenomena, such as socio-economic development, living standards, geographical cohesion or the sustainability of the transportation system.

In relation to mad (median absolute deviation) it should be noted that its particular values are obtained with the following equation:

$$
\operatorname{mad}\left(X_{j}\right)=\underset{i=1,2, \ldots, n}{\operatorname{med}}\left|x_{i j}-\theta_{j}\right|
$$

where:

med-median,

$x_{i j}$-value of the $j$-th variable for $i$-th province (voivodeship),

$i=1,2, \ldots, n-i$-th province (voivodeship),

$n$-the number of voivodeships,

$\theta_{j}$-particular values of multidimensional median vector $\Theta$ (border or Weber),

$j=1,2, \ldots, m-j$-th diagnostic variable, 
Additionally, it worth noting another normalization method in previous research, which was successfully implemented into the research process using classic statistical measures [61-63]. Moreover, the median vector (border and Weber) has already been implemented in different ways in the normalization process of the data set as well $[64,65]$.

Finally, in the case of the order method, the synthetic measure of the normalized variables is estimated with the following formula:

$$
M P_{i}=1-\frac{d_{i}}{\operatorname{med}(D)+2.5 \operatorname{mad}(D)}
$$

where:

$d_{i}$-individual values of the distance vector $D$,

$D=\left(d_{1}, d_{2}, \ldots, d_{n}\right)$-distance vector,

$\operatorname{med}(D)$-median of distance vector $D$,

$\operatorname{mad}(D)$-median absolute deviation of distance vector $D$,

2.5-constant value (immune threshold value),

The construction of each taxonomic measure requires a set of diagnostic variables that describing the subject of the research in a proper way. It is worth noting the descriptors (variables) that are usually used for the construction of spatial models in transportation research. These indicators vary widely ranging from the density of inhabitants to the accessibility and connectivity of the labor network, different types of routs, etc. [66-68].

Nevertheless, the measurement of transport sustainability is an extremely difficult task due to a number of factors that should be taken into account. This is due to the fact that there are a number of indicators that are implemented in such an investigation process [69]. Moreover, in scientific research and numerous strategic documents pertaining to European and national transport policy, there are many different research approaches to this issue. The selection of indicators that allow to measure the implementation of the concept of sustainable development, also in relation to the transport system, is the subject of ongoing discussion. The collected data should allow us to answer the question of to what extent the development in the examined case corresponds to this idea. However, the use of indicators of sustainable development is most often aimed at illustrating the degree of implementation of the principles and goals adopted in the sustainable development strategy [37]. Going further, a literature study, in combination with strategic documents, provides knowledge about a wide set of measures of sustainable transport development that have been developed in order to check the progress of introducing this transport development concept. These indicators play a special role in the globally understood transport planning process as they provide valuable information that is used in the decision-making process regarding the selection and development of policies, strategies and planning programs. Therefore, it is worth noticing that the set of diagnostic variables implemented for the assessment of sustainable transport development should take into account scientific, objective, systematic and comparable and workable principles [70].

In relation to the collection of appropriate indicators, it is worth mentioning the great influence of the work of T. Litman on the research into the evaluation of transport systems in terms of achieving the goals of sustainable development [71,72]. The list of recommended measures and indicators that should be taken into account in the process of planning and managing transport has been published. It ought to be noted that this list is updated every few years. The indicators are divided according to their significance for entity planning and managing the development of a given transport system. Furthermore, they are categorized according to the following three groups: economic, social and environmental indicators.

In spite of a wide range of indicators, the availability of data is the most important problem in the research process. In the official statistics system, data are available at various territorial levels (national, regional, local), which means that data must be aggregated. In the Polish context, it is possible to measure the degree of transport sustainability, taking into account the current availability of statistical data; the data can be analyzed using a model that includes indicators of the environmental, social and economic orders [33]. 
The indicators of the environmental order show the impact of transport on the components of the environment and express the balance between meeting social needs and maintaining the environment in an unchanged form, enabling the use of these resources for future generations [73]. The social order indicators make it possible to monitor the availability of transport infrastructure facilities and transport services for various social groups, as well as to study the negative impact of transport on society. The economic order indicators reflect the role of transport as a sector of the economy and monitor its sustainable growth. The aggregation of the indicators adopted for the assessment of individual partial orders allows for the identification of the integrated order.

Hence, our investigation process was based on the data drawn from Local Data Bank of Polish Statistics. However, it should be noted that there were two stages in the construction of the set of diagnostic variables. The first was based on the theory of the examined phenomenon and created the potential set of diagnostic variables. The second implemented basic statistical measures in order to receive the final set of diagnostic variables.

Therefore, the three main areas of sustainable transport development, measured in terms of integrated order, were taken into consideration and presented in Table 1.

To sum up, it can be stated that thirty variables formed the base for further taxonomic analysis.

Table 1. Variables used in the study.

\begin{tabular}{|c|c|}
\hline Variable & Description \\
\hline \multicolumn{2}{|r|}{ Environmental } \\
\hline$X_{1}$ & Length of railway lines in $\mathrm{km}$ per one thousand residents \\
\hline$X_{2}$ & Length of tram lines per $100 \mathrm{~km}^{2}$ of built-up and urbanized residential areas \\
\hline$X_{3}$ & Share of electrified railway tracks in their total length $(\%)$ \\
\hline$X_{4}$ & Length of bicycle paths in $\mathrm{km}$ per $100 \mathrm{~km}^{2}$ \\
\hline$X_{5}$ & Length of Park \& Ride car parks per $100 \mathrm{~km}^{2}$ of built-up and urbanized residential areas \\
\hline$X_{6}$ & Share of passenger cars over 11 years old in their total number $(\%)$ \\
\hline$X_{7}$ & Share of renewable energy in total electricity production $(\%)$ \\
\hline$X_{8}$ & Share of LPG-powered passenger cars in the total of registered cars (\%) \\
\hline$X_{9}$ & Share of passenger cars with an engine capacity of $2000 \mathrm{~cm}^{3}$ and over in their total number $(\%)$ \\
\hline$X_{10}$ & Share of bus lines in $\mathrm{km}$ in the total length of public transport bus lines $(\%)$ \\
\hline \multicolumn{2}{|r|}{ Social } \\
\hline$X_{11}$ & Road accidents per 100 thousand citizens \\
\hline$X_{12}$ & Number of people killed per 100 thousand vehicles \\
\hline$X_{13}$ & Number of injured people per 100 thousand vehicles \\
\hline$X_{14}$ & Share of two or more railway tracks in their total length ( $w \%)$ \\
\hline$X_{15}$ & Number of passengers transported in cities per citizen \\
\hline$X_{16}$ & Length of public transport lines per one thousand citizens \\
\hline$X_{17}$ & Share of urban transport lines in rural areas in their total length $(\%)$ \\
\hline$X_{18}$ & Urban roads with hard and improved surface in $\mathrm{km}$ per 10 thousand citizens \\
\hline$X_{19}$ & Country roads with hard and improved surface in $\mathrm{km}$ per 10 thousand citizens \\
\hline$X_{20}$ & Length of bicycle paths in $\mathrm{km}$ per 10 thousand citizens \\
\hline \multicolumn{2}{|r|}{ Economic } \\
\hline$X_{21}$ & Share of electricity consumption by transport sector (\%) \\
\hline$X_{22}$ & Ratio of electricity production to its consumption (\%) \\
\hline$X_{23}$ & Share of investment in trade and repair of vehicles in their total sum (\%) \\
\hline$X_{24}$ & Share of investment in transport and warehouse management in their total sum (\%) \\
\hline$X_{25}$ & Length of expressways and motorways $\left(\mathrm{km} / 1000 \mathrm{~km}^{2}\right)$ \\
\hline$X_{26}$ & National roads with hard surface $\left(\mathrm{km} / 100 \mathrm{~km}^{2}\right)$ \\
\hline$X_{27}$ & Length of standard railway tracks $\left(\mathrm{km} / 100 \mathrm{~km}^{2}\right)$ \\
\hline$X_{28}$ & Number of bridges and viaducts per $100 \mathrm{~km}^{2}$ \\
\hline$X_{29}$ & Number of lorries per one thousand citizens \\
\hline$X_{30}$ & Number of taxis per one $\mathrm{km}^{2}$ of built-up and urbanized residential areas \\
\hline
\end{tabular}




\section{Research Results and Its Discussion}

The data presented in the previous chapter, which are called the potential set of diagnostic variables, was statistically investigated for variation and correlation analysis.

The first stage, the variation analysis, was conducted with the implementation of variation coefficients. The wide range of indictors that can be implemented in this type of analysis has already been presented by Młodak [74]. The elaboration dealt with both static and dynamic variation analysis implemented into the overall variation analysis in order to prepare the final set of diagnostic variables for the taxonomic model. Therefore, basic statistical measures were calculated and presented in Table 2 for each of the analyzed orders, i.e., environmental, social and economic.

During the analysis of the data presented in Table 2, it was noticed that some of the diagnostic variables were highly skewed, i.e., $X_{5}, X_{7}, X_{11}, X_{16}, X_{18}, X_{28}$ and $X_{29}$, in every one of the analyzed orders. Furthermore, the final area, the economic order, was characterized by the extremely strong asymmetry of the following three variables: $X_{23}, X_{24}$ and $X_{27}$. Therefore, the order statistical measures, such as the median, median absolute deviation and order variation coefficients, were implemented into the research process. It is worth mentioning that these types of statistical measures should be used in the statistical verification of the potential data set and in synthetic measure construction as well. In dealing with the variation analysis, three variation coefficients were implemented. On the one hand, the investigation, based on the classical variation coefficient, proved that only the variable $X_{6}$ should be omitted. Further, the order coefficients based on the border median were introduced. The values of the border median confirmed that the variable $X_{6}$ should be removed as well. On the other hand, the introduction of the Weber median into the calculation of the order variation coefficients significantly increased its value. This was due to the fact that this kind of median takes into account mutual and not directly observed relationships. All in all, the presented consideration of the variation analysis proved that all the diagnostic variables should be included into the subsequent analysis.

The second stage of the statistical verification of the potential set of diagnostic variables was based on the correlation analysis. In order to exclude variables which carried the same information, the inverted matrix of Pearson's correlation coefficients was introduced [75]. The chosen results of the research, in the form of the main diagonals of the inverted Pearson's correlation matrices, are presented in Table 3.

Table 2. Chosen statistical measures of the set of potential variables.

\begin{tabular}{|c|c|c|c|c|c|c|c|c|c|c|}
\hline Variable & $A$ & Mean & $M_{B}$ & $M_{W}$ & $s_{X}$ & Mad (B) & $\operatorname{Mad}(W)$ & $V_{S}$ & $V_{B}$ & $V_{W}$ \\
\hline \multicolumn{11}{|c|}{ Environmental } \\
\hline$X_{1}$ & 0.39 & 5.71 & 5.62 & 3.16 & 1.72 & 1.11 & 2.46 & 30.17 & 19.82 & 77.76 \\
\hline$X_{2}$ & 0.06 & 50.87 & 63.92 & 76.22 & 45.36 & 49.09 & 36.88 & 89.17 & 76.80 & 48.39 \\
\hline$X_{3}$ & 0.22 & 59.40 & 59.41 & 9.54 & 20.35 & 18.03 & 49.87 & 34.26 & 30.36 & 522.83 \\
\hline$X_{4}$ & 0.53 & 4.94 & 4.69 & 7.54 & 1.72 & 1.32 & 2.85 & 34.86 & 28.18 & 37.86 \\
\hline$X_{5}$ & 1.93 & 7,03 & 3.52 & 14.08 & 8.71 & 3.52 & 11.51 & 123.85 & 100.00 & 81.80 \\
\hline$X_{6}$ & -0.88 & 76.75 & 78.35 & 6.36 & 4.73 & 2.43 & 71.99 & 6.16 & 3.10 & 1132.84 \\
\hline$X_{7}$ & 1.03 & 29.26 & 22.44 & 6.92 & 25.97 & 17.01 & 15.52 & 88.76 & 75.80 & 224.30 \\
\hline$X_{8}$ & 0.42 & 13.56 & 13.51 & 13.55 & 3.30 & 2.84 & 2.84 & 24.32 & 21.00 & 20.94 \\
\hline$X_{9}$ & 0.43 & 8.78 & 8.81 & 97.16 & 1.31 & 0.97 & 88.35 & 14.92 & 11.03 & 90.94 \\
\hline$X_{10}$ & 0.22 & 0.58 & 0.54 & 18.81 & 0.39 & 0.29 & 18.27 & 67.90 & 53.44 & 97.13 \\
\hline$X_{11}$ & 1.09 & 76.81 & 69.95 & 73.26 & $\begin{array}{c}\text { Social } \\
23.83\end{array}$ & 15.40 & 12.09 & 31.03 & 22.02 & 16.50 \\
\hline$X_{12}$ & -0.21 & 9.55 & 9.33 & 9.46 & 1.80 & 0.70 & 0.83 & 18.85 & 7.50 & 8.73 \\
\hline$X_{13}$ & 0.65 & 108.58 & 104.04 & 104.28 & 35.83 & 27.57 & 27.57 & 33.00 & 26.50 & 26.43 \\
\hline$X_{14}$ & -0.41 & 43.42 & 43.60 & 42.53 & 14.39 & 10.19 & 10.82 & 33.14 & 23.36 & 25.43 \\
\hline$X_{15}$ & 0.74 & 85.23 & 83.47 & 80.64 & 43.86 & 39.07 & 36.24 & 51.46 & 46.80 & 44.94 \\
\hline$X_{16}$ & 1.04 & 1.47 & 1.48 & 1.50 & 0.47 & 0.33 & 0.35 & 32.34 & 22.37 & 23.29 \\
\hline$X_{17}$ & -0.11 & 28.10 & 27.92 & 29.00 & 10.65 & 6.67 & 5.90 & 37.89 & 23.90 & 20.33 \\
\hline$X_{18}$ & 1.03 & 15.38 & 14.15 & 15.91 & 2.49 & 1.00 & 2.04 & 16.16 & 7.07 & 12.84 \\
\hline
\end{tabular}


Table 2. Cont.

\begin{tabular}{ccccccccccc}
\hline Variable & $\boldsymbol{A}$ & Mean & $\boldsymbol{M}_{\boldsymbol{B}}$ & $\boldsymbol{M}_{\boldsymbol{W}}$ & $\boldsymbol{S}_{\boldsymbol{X}}$ & $\boldsymbol{M a d}(\boldsymbol{B})$ & $\boldsymbol{M a d}(\boldsymbol{W})$ & $\boldsymbol{V}_{\boldsymbol{S}}$ & $\boldsymbol{V}_{\boldsymbol{B}}$ & $\boldsymbol{V}_{\boldsymbol{W}}$ \\
\hline$X_{19}$ & -0.14 & 64.18 & 63.35 & 62.47 & 18.07 & 7.30 & 7.30 & 28.16 & 11.52 & 11.68 \\
$X_{20}$ & -0.38 & 4.31 & 4.40 & 4.25 & 1.36 & 0.99 & 1.13 & 31.51 & 22.41 & 26.73 \\
\hline & & & & \multicolumn{7}{c}{ Economic } \\
$X_{21}$ & 0.54 & 3.22 & 3.00 & 3.16 & 1.29 & 0.91 & 0.94 & 40.12 & 30.29 & 29.60 \\
$X_{22}$ & 1.35 & 96.96 & 77.90 & 76.22 & 67.89 & 36.75 & 36.27 & 70.02 & 47.18 & 47.59 \\
$X_{23}$ & 2.77 & 9.06 & 8.05 & 9.54 & 6.01 & 2.66 & 2.81 & 66.42 & 33.07 & 29.49 \\
$X_{24}$ & 2.26 & 7.16 & 4.71 & 7.54 & 7.41 & 2.09 & 3.91 & 103.56 & 44.27 & 51.89 \\
$X_{25}$ & 0.96 & 13.53 & 11.79 & 14.08 & 6.58 & 2.67 & 4.54 & 48.63 & 22.61 & 32.26 \\
$X_{26}$ & 0.85 & 6.45 & 6.48 & 6.36 & 1.57 & 1.15 & 1.03 & 24.30 & 17.67 & 16.13 \\
$X_{27}$ & 2.38 & 6.65 & 6.25 & 6.92 & 2.77 & 1.10 & 1.44 & 41.68 & 17.55 & 20.75 \\
$X_{28}$ & 1.53 & 13.45 & 9.60 & 13.55 & 9.14 & 2.75 & 6.01 & 68.01 & 28.63 & 44.33 \\
$X_{29}$ & 1.05 & 98.59 & 94.05 & 97.16 & 14.03 & 7.75 & 9.65 & 14.23 & 8.24 & 9.93 \\
$X_{30}$ & 0.34 & 18.64 & 16.29 & 18.81 & 8.57 & 6.74 & 6.21 & 45.97 & 41.37 & 33.00 \\
\hline
\end{tabular}

Notation: $A$-skewness, $M_{B}$-border median, $M_{W}$-Weber median, $S_{X}$-standard deviation, $M a d(B)$ —median absolute deviation (border median), $M a d(W)$ - median absolute deviation (Weber median), $V_{S}$ —classic variation coefficient, $V_{B}$ —order variation coefficient based on border median, $V_{W}$-order variation coefficient based on Weber median. Source: own studies.

Table 3. Main diagonals of inverted matrices of Pearson's correlation coefficients.

\begin{tabular}{|c|c|c|c|c|c|c|c|c|c|c|}
\hline \multicolumn{11}{|c|}{ Environmental } \\
\hline & $X_{1}$ & $X_{2}$ & $X_{3}$ & $X_{4}$ & $X_{5}$ & $X_{6}$ & $X_{7}$ & $X_{8}$ & $X_{9}$ & $X_{10}$ \\
\hline Stage I & 4.98 & 2.43 & 5.75 & 6.97 & 1.44 & 10.72 & 4.30 & 3.64 & 2.50 & 5.61 \\
\hline Stage II & 2.50 & 2.36 & 5.54 & 2.28 & 1.40 & - & 4.10 & 1.93 & 2.29 & 3.84 \\
\hline \multicolumn{11}{|c|}{ Social } \\
\hline & $X_{11}$ & $X_{12}$ & $X_{13}$ & $X_{14}$ & $X_{15}$ & $X_{16}$ & $X_{17}$ & $X_{18}$ & $X_{19}$ & $X_{20}$ \\
\hline Stage I & 96.79 & 3.28 & 82.29 & 4.60 & 1.93 & 2.41 & 2.67 & 3.01 & 5.92 & 2.10 \\
\hline Stage II & - & 2.87 & 1.60 & 1.27 & 1.59 & 1.96 & 1.95 & 2.50 & 5.58 & 1.55 \\
\hline \multicolumn{11}{|c|}{ Economic } \\
\hline & $X_{21}$ & $X_{22}$ & $X_{23}$ & $X_{24}$ & $X_{25}$ & $X_{26}$ & $X_{27}$ & $X_{28}$ & $X_{29}$ & $X_{30}$ \\
\hline Stage I & 6.81 & 4.59 & 3.62 & 3.29 & 2.95 & 21.03 & 7.65 & 11.72 & 4.16 & 4.08 \\
\hline Stage II & 4.90 & 2.32 & 2.89 & 2.67 & 2.91 & - & 5.12 & 5.01 & 4.02 & 2.43 \\
\hline
\end{tabular}

Source: own studies.

It should be mentioned that the procedure for this kind of analysis has been widely presented in the polish literature [76]. Moreover, it has already been discussed at the international scientific conference organized by Statistics Poland; the results of the discussion were published and implemented into the research into living standards [77]. In this case, the analysis was carried out in two stages for each of the analyzed orders i.e., environmental, social and economic. It should be noted that the results of the first stages proved that only one variable for each of analyzed orders should be removed, i.e., $X_{6}, X_{11}$, and $X_{26}$. However, the results obtained during the second stage of the correlation analysis showed that further elimination of the diagnostic variables had to be stopped.

To sum up the statistical verification, the final set of diagnostic variables had twenty seven features that were considered as the basis for the synthetic measure construction for the particular orders in the area of transport sustainability.

In order to make the variables comparable, the normalization process was implemented separately for every analyzed order. The transformation was based on both classical and order types of standardization. In this case, the order method with border median was not included into the process of synthetic measure construction. This was due to the fact that this kind of a median is immune to skewness but does not take into account interactions in the set of diagnostic variables, which is very important in this type of analysis. Therefore, the multidimensional Weber median was the basis for the standardization of the variables in each of the analyzed orders and supported the calculation of the synthetic measure for sustainable development, measured in terms of an integrated order. 
The process of taxonomic analysis with the construction of the synthetic measure needs a definition of the character of particular features. Hence, the final set of od diagnostic variables was divided into three subsets for each of the examined orders. The first, stimulants, included the following features: $X_{1}, X_{2}, X_{3}, X_{4}, X_{7}, X_{8}, X_{14}, X_{15}, X_{16}, X_{18}, X_{19}$, $X_{20}, X_{23}, X_{24}, X_{25}, X_{27}, X_{28}$. The second, destimulants included $X_{9}, X_{12}$ and $X_{13}$. The last, nominants, consisted of $X_{5}, X_{10}, X_{17}, X_{21}, X_{22}, X_{29}$ and $X_{30}$.

Next, the implementation of the normalized variables of the three final sets of diagnostic variables allowed the synthetic measures for each of the analyzed orders (environmental, social and economic, to be constructed) to be constructed. Their values, for the both classical and the order version, are presented in Table 4.

Table 4. Values of synthetic measures according to particular orders for analyzed voivodeships.

\begin{tabular}{|c|c|c|c|c|c|c|c|c|}
\hline \multirow{2}{*}{ Voivodeship } & \multicolumn{2}{|c|}{ Environmental } & \multicolumn{2}{|c|}{ Social } & \multicolumn{2}{|c|}{ Economic } & \multicolumn{2}{|c|}{ Integrated } \\
\hline & MK & MP & MK & MP & MK & MP & MK & MP \\
\hline Dolnośląskie & 0.242 & 0.180 & 0.244 & 0.209 & 0.369 & 0.344 & 0.539 & 0.270 \\
\hline Kujawsko-Pomorskie & 0.472 & 0.453 & 0.141 & 0.104 & 0.320 & 0.288 & 0.577 & 0.374 \\
\hline Lubelskie & 0.135 & 0.194 & 0.240 & 0.296 & 0.089 & 0.170 & 0.248 & 0.182 \\
\hline Lubuskie & 0.102 & 0.115 & 0.288 & 0.235 & 0.377 & 0.326 & 0.483 & 0.210 \\
\hline Łódzkie & 0.510 & 0.432 & 0.107 & 0.103 & 0.218 & 0.103 & 0.499 & 0.126 \\
\hline Małopolskie & 0.340 & 0.235 & 0.170 & 0.209 & 0.308 & 0.318 & 0.499 & 0.299 \\
\hline Mazowieckie & 0.250 & 0.257 & 0.342 & 0.302 & 0.267 & 0.187 & 0.559 & 0.278 \\
\hline Opolskie & 0.230 & 0.068 & 0.282 & 0.286 & 0.176 & 0.261 & 0.421 & 0.140 \\
\hline Podkarpackie & 0.125 & 0.111 & 0.050 & 0.083 & 0.168 & 0.366 & 0.127 & 0.069 \\
\hline Podlaskie & 0.053 & 0.322 & 0.216 & 0.224 & 0.129 & 0.160 & 0.197 & 0.221 \\
\hline Pomorskie & 0.284 & 0.333 & 0.106 & 0.063 & 0.190 & 0.174 & 0.311 & 0.055 \\
\hline Śląskie & 0.402 & 0.244 & 0.373 & 0.308 & 0.566 & 0.603 & 0.921 & 0.772 \\
\hline Świętokrzyskie & 0.210 & 0.141 & 0.113 & 0.149 & 0.123 & 0.135 & 0.213 & -0.096 \\
\hline Warmińsko-Mazurskie & 0.141 & 0.358 & 0.025 & 0.077 & 0.117 & 0.195 & 0.078 & 0.126 \\
\hline Wielkopolskie & 0.282 & 0.209 & 0.311 & 0.290 & 0.339 & 0.354 & 0.607 & 0.412 \\
\hline Zachodniopomorskie & 0.258 & 0.354 & 0.234 & 0.197 & 0.181 & 0.115 & 0.402 & 0.171 \\
\hline
\end{tabular}

Notation: MK—classical measure, MP_order measure. Source: own studies.

The total measure for sustainable development (integrated order) is also presented in Table 4. Its values were constructed based on the synthetic measures for the particular orders in classical as well as order form. The maximum values of the synthetic measures for each of the partial analyzed orders, i.e., environmental, social and economic, were treated as stimulants in the subsequent analysis.

Next, all the presented synthetic measures were ordered monotonically. This allowed us to prepare a ranking for the level of transport development in three particular areas, as well as for the overall approach. The results of these calculations are presented in Table 5.

The constructed synthetic measures (partial and total) also made it possible to classify the surveyed voivodeships into four groups, according to both three-average and threemedian methods [57]. The results of this analysis are presented in Table 6. 
Table 5. Rankings of voivodeships according to particular orders for analyzed voivodeships.

\begin{tabular}{|c|c|c|c|c|c|c|c|c|}
\hline \multirow{2}{*}{ Voivodeship } & \multicolumn{2}{|c|}{ Environmental } & \multicolumn{2}{|c|}{ Social } & \multicolumn{2}{|c|}{ Economic } & \multicolumn{2}{|c|}{ Integrated } \\
\hline & MK & MP & MK & MP & MK & MP & MK & MP \\
\hline Dolnośląskie & 9 & 12 & 6 & 8 & 3 & 4 & 5 & 6 \\
\hline Kujawsko-Pomorskie & 2 & 1 & 11 & 12 & 5 & 7 & 3 & 3 \\
\hline Lubelskie & 13 & 11 & 7 & 3 & 16 & 12 & 12 & 9 \\
\hline Lubuskie & 15 & 14 & 4 & 6 & 2 & 5 & 8 & 8 \\
\hline Łódzkie & 1 & 2 & 13 & 13 & 8 & 16 & 7 & 12 \\
\hline Małopolskie & 4 & 9 & 10 & 9 & 6 & 6 & 6 & 4 \\
\hline Mazowieckie & 8 & 7 & 2 & 2 & 7 & 10 & 4 & 5 \\
\hline Opolskie & 10 & 16 & 5 & 5 & 11 & 8 & 9 & 11 \\
\hline Podkarpackie & 14 & 15 & 15 & 14 & 12 & 2 & 15 & 14 \\
\hline Podlaskie & 16 & 6 & 9 & 7 & 13 & 13 & 14 & 7 \\
\hline Pomorskie & 5 & 5 & 14 & 16 & 9 & 11 & 11 & 15 \\
\hline Śląskie & 3 & 8 & 1 & 1 & 1 & 1 & 1 & 1 \\
\hline Świętokrzyskie & 11 & 13 & 12 & 11 & 14 & 14 & 13 & 16 \\
\hline Warmińsko-Mazurskie & 12 & 3 & 16 & 15 & 15 & 9 & 16 & 13 \\
\hline Wielkopolskie & 6 & 10 & 3 & 4 & 4 & 3 & 2 & 2 \\
\hline Zachodniopomorskie & 7 & 4 & 8 & 10 & 10 & 15 & 10 & 10 \\
\hline
\end{tabular}

Notation: MK—classical measure, MP—order measure. Source: own studies.

Table 6. Groups of similar voivodeships according to particular orders for analyzed voivodeships.

\begin{tabular}{|c|c|c|c|c|c|c|c|c|}
\hline \multirow{2}{*}{ Voivodeship } & \multicolumn{2}{|c|}{ Environmental } & \multicolumn{2}{|c|}{ Social } & \multicolumn{2}{|c|}{ Economic } & \multicolumn{2}{|c|}{ Integrated } \\
\hline & MK & MP & MK & MP & MK & MP & MK & MP \\
\hline Dolnośląskie & III & III & II & III & I & I & II & II \\
\hline Kujawsko-Pomorskie & I & $\mathrm{I}$ & III & IV & II & II & I & I \\
\hline Lubelskie & IV & III & II & I & IV & III & III & III \\
\hline Lubuskie & IV & IV & I & II & I & II & II & II \\
\hline Łódzkie & $\mathrm{I}$ & I & III & IV & III & IV & II & IV \\
\hline Małopolskie & II & III & III & III & II & II & II & I \\
\hline Mazowieckie & III & II & I & I & II & III & II & II \\
\hline Opolskie & III & IV & I & II & III & II & II & III \\
\hline Podkarpackie & IV & IV & IV & IV & III & I & IV & IV \\
\hline Podlaskie & IV & II & II & II & IV & IV & IV & II \\
\hline Pomorskie & II & II & III & IV & III & III & III & IV \\
\hline Śląskie & I & II & I & I & I & I & I & $\mathrm{I}$ \\
\hline Świętokrzyskie & III & IV & III & III & IV & IV & IV & IV \\
\hline Warmińsko-Mazurskie & IV & I & IV & IV & IV & III & IV & IV \\
\hline Wielkopolskie & II & III & $\mathrm{I}$ & II & II & I & $\mathrm{I}$ & $\mathrm{I}$ \\
\hline Zachodniopomorskie & II & I & II & III & III & IV & III & III \\
\hline
\end{tabular}

Notation: MK—classical measure, MP_order measure. Source: own studies.

It is worth noting that the particular values of the synthetic measures were ordered monotonically. Next, rank 1 (one) was assigned to the highest value of the synthetic measure and rank 16 (sixteen) to the lowest value. Consequently, I (the first group) contained the most highly developed voivodeships. The middle-developed provinces were included in both group II (the second) and group III (the third). Finally, the fourth group (IV) contained the voivodeships with the weakest development levels.

Graphic presentations of the diversification of the integrated order and its individual areas are presented in Figures 1 and 2. 


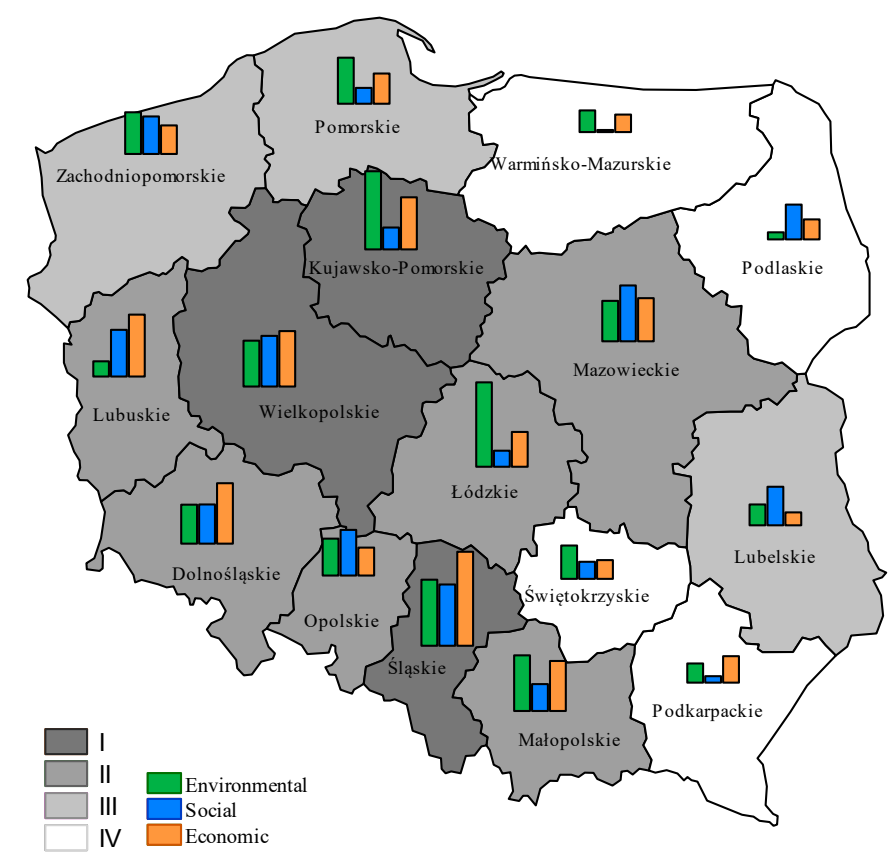

Figure 1. Diversification of sustainable transport development in particular voivodeships according to the classical measure. Note: the background of the voivodeships-the integrated order (total measure), the height of the histogram-denotes the values of the synthetic measures for particular orders i.e., environmental, social, economic. Source: own studies.

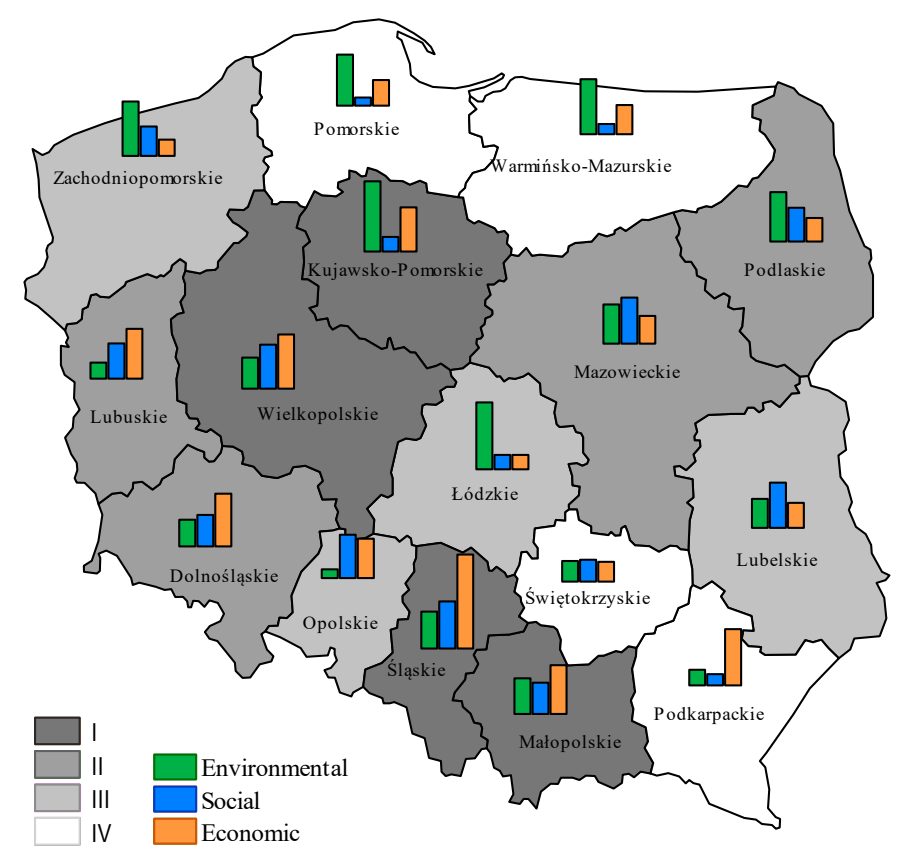

Figure 2. Diversification of sustainable transport development in particular voivodeships according to the order measure. Note: the background of the voivodeships-the integrated order (total measure), the height of the histogram-denotes the values of the synthetic measures for particular orders i.e., environmental, social, economic. Source: own studies.

As shown by the graphical presentation of the research, the classification of the voivodeships into particular groups of sustainable transport development (integrated order) differed according to the methods implemented for the synthetic measure construction. This was due to the fact that the interactions between particular diagnostic variables played a key role. Therefore, the research using both classical and order methods of synthetic mea- 
sure construction in the area of transport sustainability in Polish voivodeships brought up some interesting findings. The presented results, obtained through the taxonomic research, with the Weber median, allowed us to consider interactions in the sophisticated area of transport sustainability. However, the research was strongly limited by the availability of the data.

The analysis, based on the data delivered by Statistics Poland, according to classical and order methods, indicated that Ślaskie voivodeship can be considered as the leader. Its leadership position among all the voivodeships is combined with the area of transport sustainability measured in terms of an integrated order. It should be mentioned that this province (spatial object) took the first position in both social and economic orders. Nonetheless, in the case of the environmental order, it was noticed that this province finished in third position according to classic measure. However, the implementation of the order method using the Weber median showed a significant change in the position of this voivodeship, according to this partial order. This was due to the fact that there were very strong interactions among the variables that represented environmental order. The existence of this kind of indirectly observable relationship, before the synthetic measure construction for that area, could have been observed beforehand through the significant differences between the values of the border median and its Weber version for particular diagnostic features. Hence, it can be said that including interactions in this type of analysis significantly improves the assessment process.

Similar dependencies can be observed for the Wielkopolskie province, which took the second position in the ranking, according to both measures for the integrated order. On one hand, this voivodeship took higher positions in the area of both social and economic order. One the other hand, is earned a relatively low position in terms of the environmental order.

The third place among the leading provinces was occupied by Kujawsko-Pomorskie. Both synthetic measures confirmed its position in the constructed ranking of transport sustainability measured in terms of the integrated order. In relation to the previous cases (Ślaskie and Wielkopolskie), this voivodeship had a low position in the area of social order.

The constructed ranking of sustainable development proved that the weakest places are occupied by the following three provinces: Warmińsko-Mazurskie, Podkarpackie and Świettokrzyskie. It should be noted that in all cases, the implementation of both methods of synthetic measure construction (classical and order) did not confirm their locations as it did the leading group. Moreover, the differences were observed in most of the detailed orders. Only Świętokrzyskie province could be considered as the exception to the rule in the area of the economic order. This was due to its weak economic position, assessed according to both synthetic measures.

The latter groups, i.e., the remaining ten voivodships, had slight differences in ranking according to the implemented version of the synthetic measure construction. However, the research results showed that one very interesting case in connection with Podlaskie voivodeship. This Polish province was ranked as fourteenth in the general classification according to the classical measure and seventh according to order measure with the Weber median. Firstly, its weak position in the area of the environmental order according to classic method may be worrying and confusing. Secondly, the inclusion of interactions significantly changed its position in this analysis area. Due to the fact that Podalaskie province is thought of as the green lungs of Poland, the implementation of the order method with the Weber median seems to be appropriate in this type of research.

The results obtained allowed us to perform the geographical assessment for the three orders separately, which can be very helpful in the construction of investment projects. However, it is worth mentioning that the implementation and development of technical infrastructure is not possible without meaningful investment projects [78].

The highest-ranked voivodeships in the first area, the environmental order, were Kujawsko-Pomorskie and Łódzkie. Podkarpackie voivodeship was considered the lowest in that area. 
The second area, i.e., the social order, featured the following highest-ranked voivodships: Śląskie, Mazowieckie and Wielkopolskie. The lowest ranks in this group were taken up by Warmińsko-Mazurskie, Podkarpackie and Pomorskie provinces.

The last area was characterized substantial differences between its rankings of the voivodeships and the rankings in the economic order. On the one hand, Slaskie could be considered the undisputed leader. On the other hand, the following voivodships of Eastern Poland were ranked the lowest: Lubelskie, Podlaskie, Świętokrzyskie.

According to the results of the presented analysis, a negative correlation was observed between the social and economic orders and the environmental order. In the case of the geographical regions characterized by high indicator values in the environmental order (Łódzkie, Kujawsko-Pomorskie, Pomorskie), low indicators of economic and social order were also recorded. The analysis also proved that higher positions in the ranking of voivodships in the area of social order were reflected in higher positions in the ranking of the overall integrated order.

To sum up the discussion of the results, the implementation of the order synthetic measure with the Weber median allowed us to include indirectly observable information about complex transport sustainability. Consequently, this enriched the analysis and brought the results closer to the directly observable reality.

\section{Conclusions}

This research into sustainable transport development, using both methods of synthetic measure construction (classical and order), in Polish provinces (voivodeships) led to conclusions concerning both the methods implemented in the research process and the level of transport sustainability of the analyzed voivodeships.

The former showed that the statistical investigation of a potential set of diagnostic variables should include more than classical measures, such as the arithmetic mean, standard deviation and classic variation coefficient. Consideration of the high level of skewing among some of the diagnostic variables obliged us to implement order statistical measures as well, such as the median, median absolute deviation and order variation coefficients. The strong skewing of the empirical distributions was observed in every data set describing the examined orders (environmental, social and economic). It should be noted that the implementation of the order variation coefficients, with both the border and Weber median, confirmed the acceptance of particular variables for subsequent analysis.

In terms of the correlation analysis, interactions were taken into account through the introduction of the inverted matrix Pearson's correlation coefficients.

The importance of including mutual, but not directly observable, relationships among diagnostic variables in the process of synthetic measure construction was explored using the values of the Weber median. In the case of some variables, this value turned out to be significantly different to its border version.

Consequently, the strong asymmetry of some variables and mutual interactions in the three sets of diagnostic variables, for every one of the examined orders, proved that the order method of synthetic measure construction with Weber median needed to be introduced. In addition to its failure to include the mutual and not directly observable relationships (interactions) among particular variables, the application of the classical method may have had a negative impact on the constructed rankings of the examined multidimensional objects (voivodeships) because the empirical distributions of the diagnostic variables were highly skewed. The latter observations, based on the results obtained in the carried out research, led us to several synthetic conclusions about the levels transport sustainability in particular voivodeships.

Firstly, they showed that the level of sustainable transport development should be considered as an extremely sophisticated phenomenon.

Secondly, the analysis of rankings, constructed according to the classical measure, showed that the leading place in Poland, in the context of transport sustainability (integrated order), was taken by three voivodeships: Ślaskie, Wielkopolskie and Kujawsko- 
Pomorskie. These leading positions were confirmed by the values of the order synthetic measure with the Weber median. For the voivodeships in the leading positions, the values of the variables that were considered as stimulants were relatively high in each of the examined orders, i.e., environmental, social and economic.

Thirdly, the analysis showed significant differences in the case of the weakest group, according to both the methods of synthetic measure construction. It should be noted that only in the case of Ślaskie did both methods confirm the same position.

To sum up, the research indicates a certain regularity of geographical development in the area of transport sustainability. It should be mentioned that there were significant geographical disproportions in the development level of sustainability of transportation system in analysed voivodeships. To some extent, the presented results reflected socioeconomic development levels. The voivodeships located in both the north-eastern and south-eastern regions can be considered more underdeveloped in the area of transport sustainability. Nevertheless, Pomorskie province can be treated as the exception to the rule according to the order method. This is due to the implementation of the Weber median in the process of the synthetic measure construction and to the consideration of mutual and not directly observable relationships. We claim that the findings of this study will facilitate this type of analysis and offer a contribution to further studies in dynamic form. The problems discussed in this article, as well as the proposed methodology, can be applied by responsible entities to the planning and implementation transport policy. Moreover, constant monitoring of the development processes of regional transport systems may support decision-making processes with regards to the optimization of the size and structure of investment outlays. It should further contribute to the balancing of transport systems in the environmental, social and economic dimensions. Our research indicates that the monitoring of sustainable transport at the regional level is limited by the difficulties related to the creation of indicators reflecting individual spheres of sustainable development. The lack of many data from public statistics at the regional level in the Polish system makes it impossible to create a full module of indicators reflecting individual spheres of sustainable transport development. Further studies should focus on improving the currently functioning indicators of sustainable transport, as well as on constructing new ones, which would allow improved descriptions of the issues under study.

Author Contributions: Conceptualization, A.C., A.K., M.K. and K.G.; methodology, A.C., A.K., M.K. and K.G.; software, A.C.; validation, A.C., A.K., M.K. and K.G.; formal analysis, A.C., A.K., M.K. and K.G.; investigation, A.C., A.K., M.K. and K.G.; resources, A.C., A.K., M.K. and K.G.; data curation, A.C., A.K., M.K. and K.G.; writing-original draft preparation, A.C., A.K., M.K. and K.G.; writingreview and editing, A.C., A.K., M.K. and K.G.; visualization, A.C., A.K., M.K. and K.G.; supervision, A.C., A.K., M.K. and K.G.; project administration, A.C., A.K. and M.K.; funding acquisition, A.C., A.K., M.K. and K.G. All authors have read and agreed to the published version of the manuscript.

Funding: This research received no external funding.

Institutional Review Board Statement: Not applicable.

Informed Consent Statement: Not applicable.

Data Availability Statement: The source of data is available form BDL (Bank of Local Data) published on the web side Statistics Poland: https:/ /bdl.stat.gov.pl/BDL/dane/podgrup/temat/ (accessed on 15 May 2021).

Conflicts of Interest: The authors declare no conflict of interest.

\section{References}

1. Gratiela, B. Sustainable consumption in the area of transportation. Constanta Marit. Univ. Ann. 2013, 14, $209-212$.

2. Air Pollution: Our Health Still Does Not Have Sufficient Protection; Special Report Persulant to Article 287(4), Second Subparagraph; TFEU/European Court of Auditors: Luxembourg, 2018. Available online: https:/ /op.europa.eu/webpub/eca/special-reports/ air-quality-23-2018/en/ (accessed on 14 May 2021).

3. Kumar, S.; Hoffmann, J. Globalization: The Maritime nexus. In Handbook of Maritime Economics and Business; Grammenos, C., Ed.; Loyds List Press: London, UK, 2002; pp. 35-62. 
4. Bąk, I.; Barwińska-Małajowicz, A.; Wolska, G.; Walawender, P.; Hydzik, P. Is the European Union Making Progress on Energy Decarbonisation While Moving twoards Sustaianble Development? Energies 2021, 14, 3792. [CrossRef]

5. Roadmap to a Single European Transport Area-Towards a Competitive and Resource Efficient Transport System; White Paper; European Commission: Brussels, Belgium, 2011. Available online: https:/ / eur-lex.europa.eu/legal-content/EN/TXT/?uri=CELEX\%3A520 11DC0144 (accessed on 15 May 2021).

6. Persia, L.; Cipriani, E.; Sgarra, V.; Meta, E. Strategies and measures for sustainable transport systems. Transp. Res. Procedia 2016, 14, 955-964. [CrossRef]

7. López, E.; Guitérrez, J.; Gómez, G. Measuring regional cohesion effects on large-scale transport infrastructure investments: An accessibility approach. Eur. Plan. Stud. 2008, 16, 277-301. [CrossRef]

8. Our Common Future. Report of the World Commission on Environment and Development. Available online: http://www.undocuments.net/wced-ocf.htm (accessed on 14 May 2021).

9. United Nations. Report of the United Nations Conference on Environment and Development, Rio de Janeiro, 3-14 June 1992. Volume 2, Proceedings of the Conference; UN: New York, NY, USA, 1993; ISBN 921-100498-5. Available online: https: / / digitallibrary.un.org/ record / 168679\#record-files-collapse-header (accessed on 15 May 2021).

10. Garrigos-Simon, F.; Botella-Carrubi, D.; González-Cruz, T. Social Capital, Human Capital, and Sustainability: A Bibliometric and Visualization Analysis. Sustainability 2018, 10, 4751. [CrossRef]

11. Islam, S.M.; Munasinghe, M.; Clarke, M. Making long-term economic growth more sustainable: Evaluating the costs and benefits. Ecol. Econ. 2003, 47, 149-166. [CrossRef]

12. Abrahams, G. Constructing definitions of sustainable development. Smart Sustain. Built Environ. 2017, 6, 34-47. [CrossRef]

13. Beckerman, W. 'Sustainable development': Is it a useful concept? In The Economics of Sustainability; Routledge: London, UK, 2017; pp. 161-179.

14. Daly, H.E. Sustainable development—Definitions, principles, policies. In The Future of Sustainability; Springer: Berlin/Heidelberg, Germany, 2006; pp. 39-53.

15. Franks, T.R. Managing sustainable development: Definitions, paradigms, and dimensions. Sustain. Dev. 1996, 4, 53-60. [CrossRef]

16. Kiel, J.; Smith, R.; Ubbels, B. The Impact of Transport Investments on Competitiveness. Transp. Res. Procedia 2014, 1, 77-88. [CrossRef]

17. Purwanto, A.J.; Heyndrickx, C.; Kiel, J.; Betancor, O.; Socorro, M.P.; Hernandez, A.; Eugenio-Martin, J.L.; Pawlowska, B.; Borkowski, P.; Fiedler, R. Impact of Transport Infrastructure on International Competitiveness of Europe. Transp. Res. Procedia 2017, 25, 2881-2892. [CrossRef]

18. Grzelakowski, A.S. The concept of internalisation of the external costs of transport in the EU' and its impact on the efficiency of transport systems and the performance of logistics supply chains. Prace Naukowe Uniwersytetu Ekonomicznego we Wroctawiu 2020, 64, 161-174. [CrossRef]

19. Chatziioannou, I.; Alvarez-Icaza, L.; Bakogiannis, E.; Kyriakidis, C.; Chias-Becerril, L. A Structural Analysis for the Categorization of the Negative Externalities of Transport and the Hierarchical Organization of Sustainable Mobility's Strategies. Sustainability 2020, 12, 6011. [CrossRef]

20. Demir, E.; Huang, Y.; Scholts, S.; Woensel, T. A selected review on the negative externalities of the freight transportation: Modeling and pricing. Transp. Res. Part E Logist. Transp. Rev. 2015, 77, 95-114. [CrossRef]

21. Litman, T.; Burwell, D. Issues in sustainable transportation. Int. J. Glob. Environ. Issues 2006, 4, 331-347. [CrossRef]

22. Paprocki, W. Transport drogowy. In System Transportowy Polski; Pieriegud, J., Ed.; SGH: Warszawa, Poland, $2015 ;$ pp. 13-35.

23. Pawłowska, B. Koszty zewnętrzne transportu w Polsce. Przegląd Nauk. Inżynieria Kształtowanie Sr. 2018, 27, 28-41. [CrossRef]

24. Strategia Rozwoju Transportu do 2020 r. (z perspektywą do 2030 r.).-M.P.2013.75. Available online: https:// sip.lex.pl/aktyprawne/mp-monitor-polski/strategia-rozwoju-transportu-do-2020-r-z-perspektywa-do-2030-r-17953349 (accessed on 14 June 2021).

25. Grzelakowski, A. Zrównoważenie systemu transportowego drogą do nowoczesności sektora transportu UE. Logistyka 2014, 4, 2827-2837.

26. Motowidlak, U. Rozwój transportu a paradygmat zrównoważonego rozwoju. Studia Ekon. 2017, 337, $138-152$.

27. Motowidlak, U.; Kujawa, M. Transport Towarów w Projekcie One Belt and One Road jako Component Globalnego Łańcucha Dostaw; Wydawnictwo Uniwersytetu Łódzkiego: Łódź, Poland, 2018; p. 36.

28. Tolley, R. Sustainable Transport; Woodhead: Cambridge, UK, 2003.

29. ECMT. Assessment E Decision Making for Sustainable Transport, European Conference of Ministers of Transport; OECD: Paris, France, 2004; p. 17.

30. Wiederkehr, P.; Gilbert, R.; Crist, P.; Caïd, N. Environmentally Sustainable Transport (EST): Concept, Goal, and Strategy-The OECD's EST Project. Eur. J. Transp. Infrastruct. Res. 2004, 4, 11-25. [CrossRef]

31. Borys, T. Zrównoważony rozwój-jak rozpoznać ład zintegrowany. Probl. Ekorozw. 2011, 6, 75-81.

32. Matuszczak, A. Koncepcja zrównoważonego rozwoju w obszarze ekonomicznym, środowiskowym i społecznym. Rocz. Ekon. Kuj.-Pomor. Szkoły Wyższej w Bydg. 2009, 2, 125-141.

33. Przybyłowski, A. Pomiar zrównoważonego rozwoju transportu w polskich województwach. Optim. Studia Ekon. 2014, 3, 184-194. [CrossRef] 
34. Kusideł, E. Zbieżność poziomu rozwoju województw Polski w kontekście kształtowania ładu instytucjonalnego. Optim. Studia Ekon. 2014, 3, 103-117. [CrossRef]

35. Panfiluk, E. Kształtowanie ładu przestrzennego w świetle koncepcji zrównoważonego rozwoju. Ekon. Sr. 2003, 1, $162-177$.

36. Klóska, R. Rozwój zrównoważony regionów w Polsce w ujęciu statystycznym. Prog. Econ. Sci. 2017, 4, 159-176.

37. Adamowicz, M.; Smarzewska, A. Model oraz mierniki trwałego z zrównoważonego rozwoju obszarów wiejskich w ujęciu lokalnym [Model and indicators of sustainable development in rural areas from the local perspective]. Zesz. Nauk. SGGW Polityki Eur. Finans. i Mark. 2009, 1, 251-252.

38. Figura, J. Taksonomia w Polityce Logistycznej Państwa [Taxonomy in Logistic Policy of State]; Uniwersytet Ekonomiczny: Katowice, Poland, 2013.

39. Janic, M. Sustainable Transport in the European Union: A Review of the Past Research and Future Ideas. Transp. Rev. 2006, 26, 81-104. [CrossRef]

40. Cheba, K.; Saniuk, S. Sustainable urban transport-The concept of measurement in the field of city logistics. Transp. Res. Procedia 2016, 16, 35-45. [CrossRef]

41. Ahmad, S.; de Oliveira, J.A.P. Determinants of urban mobility in India: Lessons for promoting sustainable and inclusive urban transportation in developing countries. Transp. Policy 2016, 50, 106-114. [CrossRef]

42. Malasek, J. A set of tools for making urban transport more sustainable. Transp. Res. Procedia 2016, 14, 876-885. [CrossRef]

43. Markova, I.; Shubenkova, K.; Gabsalikhova, L. Analysis of the city transport system's development strategy designed principles with account of risks and specific features of spatial development. Transp. Probl. 2017, 12, 125-138. [CrossRef]

44. Lopez-Carreiro, I.; Monzon, A. Evaluating sustainability and innovation of mobility patterns in Spanish cities. Analysis by size and urban typology. Sustain. Cities Soc. 2018, 38, 684-696. [CrossRef]

45. Illahi, U.; Shafi Mir, M. Assessment of transport sustainability using a hybrid approach: A comperison of four metropolitan cities of India. Case Stud. Transp. Policy 2021, 9, 703-714. [CrossRef]

46. Kiba-Janik, M.; Thompson, R.; Cheba, K. An assessment tool of the formulation and implementation a sustainable integrated passenger transport strategies. An example of selected European and Australian cities. Sustain. Cities Soc. 2021, 71, 1-10. [CrossRef]

47. Ahangari, H.; Garrick, N.W.; Atkinson-Palombo, C. Relationship between human capital and transportation sustainability for the United States and selected European Countries. J. Transp. Res. Board 2016, 2598, 92-101. [CrossRef]

48. De Gruyter, C.; Currie, G.; Rose, G. Sustainability measures of urban public transport in cities: A world review and focus on the Asia/Middle East Region. Sustainability 2017, 9, 43. [CrossRef]

49. Hajduk, S. Assessment of urban transport-A comparative analysis of selected cities by taxonomic methods. Econ. Manag. 2016, 8, 67-74. [CrossRef]

50. Czech, A.; Lewczuk, J. Taxonomic and econometric analysis of road transport development in Poland-The voivodship approach Ekon. Zarzadzanie 2016, 4, 88-100. [CrossRef]

51. Czech, A.; Lewczuk, J. Statistical assessment of the development of the transportation system in chosen countries-An international approach. Procedia Eng. 2017, 182, 112-119. [CrossRef]

52. Fanni, Z.; Khakpour, B.A.; Heydari, A. Evaluating the regional development of border cities by TOPSIS model (case study: Sistan and Baluchistan Province, Iran). Sustain. Cities Soc. 2014, 10, 80-86. [CrossRef]

53. Czech, A.; Biezdudnaja, A.; Lewczuk, J.; Razumowskij, W. Quantitative assessment of urban transport development-A spatial approach. Eng. Manag. Prod. Serv. 2018, 10, 32-44. [CrossRef]

54. Cheba, K. Taksonomiczna analiza rozwoju transportu drogowego w Polsce [Taxonomic analysis of road transport development in Poland]. Logistyka 2011, 2, 97-106.

55. Ewing, R.; Cervero, R. Travel and the built environment: A synthesis. Transp. Res. Rec. J. Transp. Res. Board 2001, 1780, 87-113. [CrossRef]

56. Vörös, T.; Juhász, M.; Koppány, K. The measurement of indirect effects in project appraisal. Transp. Res. Procedia 2015, 13, 114-123. [CrossRef]

57. Matteis, T.; Liedtke, G.; Wisetjindawat, W. A framework for incorporating market interactions in an agent based model for freight transport. Transp. Res. Procedia 2016, 12, 925-937. [CrossRef]

58. Hellwig, Z. Zastosowanie metody taksonomicznej do typologicznego podziału krajów ze względu na poziom ich rozwoju oraz zasoby i strukture wykwalifikowanych kadr [Application of the taxonomy method to typology classification of the countries because of the development level or resources and the structure of human resources]. Przeglad Stat. 1968, 4, $307-327$.

59. Młodak, A. Analiza Taksonomiczna w Statystyce Regionalnej [Taxonomic Analysis in Regional Policy]; Difin: Warszawa, Poland, 2006.

60. Lira, J.; Wagner, W.; Wysocki, F. Mediana w Zagadnieniach Porządkowania Obiektów Wielocechowych [Median in the Ordering Issues of Multivariable Objects]. In Statystyka Regionalna w Stużbie Samorzadu Lokalnego i Biznesu [Regional statistics in duty of local government]; Paradysz, W.J., Ed.; Akademia Ekonomiczna: Poznań, Poland, 2002; pp. 87-99.

61. Jajuga, K.; Walesiak, M. Standardization of data set under different measurement scales. In Classification and Information Processing at the Turn of the Millennium; Decker, R., Gaul, W., Eds.; Springer: Berlin/Heidelberg, Germany, 2000; pp. $105-112$.

62. Zielińska-Sitkiewicz, M. The impact of normalization procedures on the classification of building material companies listed on the Warsaw Stocl Exchange. Polityki Eur. Finans. Mark. 2017, 18, 272-281. [CrossRef] 
63. Debkowska, K.; Jarocka, M. The impact of the method of the data normalization on the results. Folia Oeconomica 2013, 286, 181-188.

64. Czech, A. Application of chosen normalization methods in the process of construction of synthetic measure in indirect consumption research. Folia Oeconomica 2014, 3, 231-240.

65. Czech, A.; Lewczuk, J.; Bortłomiuk, A. Multidimensional assessment of the European Union transport development in the light of implemented normalization methods. Econ. Manag. 2016, 8, 75-85. [CrossRef]

66. Steal, D.; Marshall, S. The relationship between urban form and travel patterns. Int. Rev. Eval. Eur. J. Transp. Infrastruct. Res. 2001, 1, 113-141. [CrossRef]

67. Sánchez-Diaz, I.; Holguin-Veras, J.; Wang, X. An exploratory analysis of spatial effects on fright trip attraction. Transportation 2014, 43, 177-196. [CrossRef]

68. Ducret, R.; Lemarié, B.; Roset, A. Cluster analysis and spatial modeling for urban fright. Identifying homogeneous urban zones based on urban form and logistics characteristics. Transp. Res. Procedia 2016, 12, 301-313. [CrossRef]

69. Gratiela, B.; Viorela-Georgiana, C. Sustainable transport's indicators. Comparative study: Eu-27 and Romania. Constanta Marit. Univ. Ann. 2013, 14, 267-270.

70. Li, Y.; Yang, J.; Shi, H.; Li, Y. Assessment of sustainable transport development based on entropy and unascertained measure. PLoS ONE 2017, 12, 1-9. [CrossRef] [PubMed]

71. Litman, T. Developing indicators for comprehensive and sustainable transport planning. Transp. Res. Rec. J. Transp. Res. Board 2007, 2017, 10-15. [CrossRef]

72. Litman, T. Sustainable transportation indicators: A recommended program to define a standard set of indicators for sustainable transportation planning. Transp. Res. Rec. 2008. [CrossRef]

73. Bartniczak, B. Zrównoważony transport na poziomie regionalnym jako przedmiot pomiaru wskaźnikowego. Studia Ekon. 2013, 143, 11-20.

74. Młodak, A. Ocena zmienności cech statystycznych w modelu taksonomicznym [The evaluation of the variability of statistical features in the taxonomic model]. Wiadomości Stat. 2005, 9, 5-18.

75. Malina, A.; Zeliaś, A. On building taxsonometric measure of living conditions. Stat. Transit. 1997, 3, 523-544.

76. Panek, T.; Zwierzchowski, J. Statystyczne metody wielowymiarowej analizy porównawczej. Teoria i zastosowania. [Statistical methods of multivariate comparative analysis]. In Theory and Practice; SGH: Warszawa, Poland, 2013.

77. Czech, A.; Słaby, T. Ocena poziomu życia gospodarstw domowych według województw-meandry analizy taksonomicznej [The assessment of Polish households living standards in voivodeships-the meanders of taxonomic analysis]. Wiadomości Stat. 2017, 10, 19-37.

78. Бездудная, А.Г.; фраймович, Д.Ю. Диагностика эффективности инвестиций в воспроизводственных процессах региональных инновационных систем[Diagnostics of investment efficiency in the reproductive processes of regional innovation systems]. Конкурентоспособность вГлобальном Мире Экономика Наука Технологии 2016, 7, 35-39. 